\title{
THE EFFECTS OF VPTI'S CORPORATE IMAGE AND SERVICE QUALITY ON SATISFACTION AND LOYALTY OF THE KSO SCISI CUSTOMERS
}

\author{
Arie Satryo Wibowo*), Heny K Suwarsinah *), and Lilik Noor Yuliati**) \\ *) School of Business Bogor Agricultural University \\ Jl. Raya Pajajaran, Bogor-Indonesia 16151 \\ **) The Department of Family and Consumer Science, Faculty of Human Ecology, Bogor Agricultural University \\ Jl. Lingkar Akademik, Kampus IPB Dramaga, Bogor
}

\begin{abstract}
This research aimed to measure the Customer Satisfaction Index (CSI) and Customer Loyalty Index (CLI), analyze the effects of service quality and corporate image on customer satisfaction, analyze the effects of service quality and corporate image on customer loyalty, analyze the effects of customer satisfaction on customer loyalty, analyze the indicators of service quadrants required to be improved by using the Cartesian diagram, and analyze the managerial implications for the company in an effort to improve customer satisfaction and customer loyalty. The method used in the research was surveys supported by questionnaires to the customers of importers of KSO SCISI. The determination of the respondents was carried out using the nonprobability sampling, and the data were analyzed using CSI (Customer Satisfaction Index), CLI (Customer Loyalty Index), Structural Equation Modeling Linear Structural Relationship (SEM LISREL) and IPA (Importance Performance Analysis). The results of the research show that service quality had positive effects on customer satisfaction, the corporate image had positive effects on customer satisfaction, the service quality had positive and significant effects on customer loyalty, and the corporate image had positive effects on customer loyalty while customer satisfaction had no positive effects on loyalty. The Customer Satisfaction Index indicates that the customers were satisfied with the services provided by KSO SCISI, and the Customer Loyalty Index also indicates that the customers were loyal to the services provided by KSO SCISI.
\end{abstract}

Keywords: KSO SCISI, VPTI, customer satisfaction, customer loyalty, SEM, lisrel

\begin{abstract}
Abstrak: Penelitian ini bertujuan mengukur Indeks Kepuasan Pelanggan (CSI) dan Indeks Loyalitas Pelanggan (CLI), menganalisis pengaruh kualitas pelayanan dan citra perusahaan terhadap kepuasan pelanggan, menganalisis pengaruh kualitas pelayanan dan citra perusahaan terhadap loyalitas pelanggan, menganalisis pengaruh kepuasan pelanggan terhadap loyalitas pelanggan, menganalisis indikator kuadran layanan yang harus diperbaiki dengan menggunakan diagram kartesius dan implikasi manajerial bagi perusahaan dalam upaya meningkatkan kepuasan pelanggan dan loyalitas pelanggan. Metoda penelitian dengan melakukan suvai kepada importir pelanggan KSO SCISI yang dipandu dengan kuisioner. Penentuan responden dilakukan secara non probability sampling. Teknik analisis data menggunakan CSI (Customer Satisfaction Index), CLI (Customer Loyalty Index), Structural Equation Modelling Linear Structural Relationship (SEM LISREL) dan IPA (Importance Performance Analysis). Hasil Penelitian menunjukkan bahwa kualitas pelayanan berpengaruh positif signifikan terhadap kepuasan pelanggan, citra perusahaan berpengaruh positif signifikan terhadap kepuasan pelanggan, kualitas layanan berpengaruh positif signifikan terhadap loyalitas pelanggan, citra perusahaan berpengaruh positif signifikan terhadap loyalitas pelanggan, kepuasan pelanggan berpengaruh signifikan positif terhadap loyalitas. Indeks Kepuasan Pelanggan menunjukkan bahwa pelanggan puas dengan pelayanan yang dilakukan KSO SCISI dan Indeks loyalitas pelanggan juga menunjukkan bahwa pelanggan termasuk loyal terhadap layanan yang dilakukan oleh KSO SCISI.
\end{abstract}

Kata kunci: KSO SCISI, VPTI, kepuasan pelanggan, loyalitas pelanggan, SEM, lisrel

\footnotetext{
${ }^{1}$ Corresponding author:

Email: satryoscisi@gmail.com
} 


\section{INTRODUCTION}

One role of services in international trade is the role of control over imported goods that is to ensure the conformity of imported goods in terms of regulatory provisions, quality, quantity, type and specification of commodities as stated in import documents through Verification and Technical Inquiry Program on Import activities (VPTI). For this role, the government in this case the Ministry of Trade appointed PT Sucofindo and PT Surveyor Indonesia as the State-Owned Enterprises (SOEs) to establish an operational cooperation with KSO Sucofindo - Surveyor Indonesia (KSO SCISI) which is responsible for assisting the government in controlling imported goods (Kemendag, 2016 ).

Verification and Technical Inquiry Program on Imports (VPTI) is one form of import control policy imposed on the import of goods through inspection in the cargo loading country by a surveyor appointed by the Minister of Trade. The results are presented in the Surveyor Report (LS) as one of the documents required in the disposal of imported goods. The aims of VPTI are to: (1) ensure compliance between the licensing documents and the import documents and physical goods, thereby avoiding the entry of unsuitable goods/non-compliance goods, (2) ensure that some products fulfill the technical standards/quality, and (3) obtain and provide accurate import data. The benefits of VPTI are: (1) improving the conformity of goods under the terms of the contract of sale and having more controlled volumes of imported goods; (2) improving the performance (compliance) of the importers on import provisions; and (3) providing accurate and up-to-date data for the government policy making (KSO SCISI, 2016).

To date, the management of KSO SCISI is facing a monopoly market in VPTI service in Indonesia; however, if it is unable to provide excellent services and good corporate image, it is feared that there will be rejections from importers because they are not satisfied with the services they obtain. As a surveyor of imported goods, KSO SCISI offices are evaluated annually by the government. To create continuous cooperation, KSO SCISI must be able to perform its duties properly in accordance with the initial objective of the establishment of KSO SCISI that is to supervise the government regulation and become the partner for the importers through VPTI activity.
Therefore, KSO SCISI must pay attention to the growing needs and expectations of its customers and try to meet their expectations by providing a more satisfactory service than that of its competitors. Only qualified companies that have good corporate image can compete and dominate the market. KSO SCISI management seeks to improve performance, competitiveness, image and service by evaluating its performance that has been implemented so that its customers can obtain maximum satisfaction in accordance with their expectations.

A number of studies show that service quality positively affects satisfaction, and satisfaction affects loyalty as it has been proven by the research conducted by Prihanto (2013) on hotel servants; Sanjaya (2016) an instant noodle customers in Denpasar city; Seffy et al. (2014) on the service of Garuda Indonesia Palembang; Anzie and Arifn (2015) on customer service of BCA; Ong and Pambudi (2014) on SBU Laboratory service; Nurfina et al.(2016) on the service of Garuda Online Shop Airlines; Wendha et al. (2013) on Garuda Indonesia service, Panjaitan (2014) on PT.Sucofindo service; Hidayati and Firdaus (2014) on telecom speedy service; Afsar and Nasiri (2013) on E-Commerce services; Rifai and Suryani (2016) on online ticket service; Safitri (2016) on Samsung Service Center customers; Annisa (2014) on the service of PT. Surveyor Indonesia, Dhiranty et al. (2017) on Tokopedia.com online shop service, Nugroho (2016) on Telkom Speedy and Hami et al. (2016) on service in Honda Service Center AHASS

Some other studies mentioned that the services of a monopolistic market are not satisfactory, but the customers are loyal. This can be proven by Gultom et al. (2016); Wahyudi et al. (2016) stating that this condition occurs because there is no other option in seeking for a better service.

In an increasingly competitive business competition, there has been a change in business behavior, which is not just relying on customer satisfaction. In the past the company considers that a satisfied customer is enough, because it will surely be loyal consumer, but apparently some studies suggest that although satisfied customers are not necessarily loyal. There are other service companies that provide better service then will move to competitors (Yesenia and Siregar, 2014). The enactment of the AEC will have implications for the management of KSO SCISI that should be must be able to compete with overseas surveyor firm operating in the ASEAN Countries. 
Maintain customer loyalty of the competition of the competition entry of overseas surveyor then KSO SCISI management provide service that meet customer demand and quality of corporate image so as to produce maximum satisfaction. Maximum will ensure the creation of customer loyalty.

Constantly evolving consumer demands in line with the development of information technology, the experiences gained to services elsewhere and demands in the business competition. Expectations so that consumers of a service has always been progressing rapidly. It is if it is not followed by the development in the improvement of services by the company will result in gaps that cause dissatisfaction in these services (Sudikan, 2010). Based on the results of the survey report 2016 KSO SCISI decline in the level of satisfaction on the service VPTI in KSO SCISI in 2014 and 2015. In 2012 and 2013 the CSI figure of $75.80 \%$ and $76.80 \%$, then in 2014 fell to $74.01 \%$ and in 2015 fell to $73.20 \%$.

There is still some complaints of customers KSO SCISI about services received, especially in the last two years show that the conditions of service quality is not maximized in accordance with customers' expectations. This condition requires improvement in the quality of services in order to generate maximum satisfaction. Also the seriousness of the KSO SCISI to give a good corporate image, quality as well as maintaining the company's reputation will certainly affect customer satisfaction and loyalty.

Satisfaction will be maximized if the level of the company's performance is the quality of service in accordance with the level of customer expectations. Not to observed satisfaction level and the level of customer loyalty in services in KSO SCISI VPTI, as well as how linkages between corporate image and service quality to customer satisfaction and loyalty it is important to do research.

Generally, this study aimed to analyze the relationship between corporate image and quality of service VPTI towards customer satisfaction and loyalty SCISI KSO. Detailed research purposes are: (1) Measuring consumer satisfaction index (CSI) and consumer loyalty index (CLI) on SCISI KSO VPTI services; (2) Analyzing the impact of service quality and corporate image on customer satisfaction; (3) to analyze the impact of service quality and corporate image on customer loyalty; (4) To analyze the effect of customer satisfaction on customer loyalty; (5) Analyze the quadrant indicator of service quality should be improved by using Cartesian diagram; (6) To formulate managerial implications for companies in an effort to improve customer satisfaction and customer loyalty.

The scope of this research was limited to the VPTI services conducted by KSO SCISI in the service period of 2015 on all kinds of imported goods subject to the VPTI rules based on the Trade Ministry Decree (Permendag RI) of 2002, and this research was limited only to importers domiciled in Jakarta and the surrounding areas.

\section{METHODS}

The research was conducted at the Head Office of KSO Sucofindo-Surveyor Indonesia located at L'Avanue Office Tower, Floors 8 \& 9, Pancoran South Jakarta in which the research data were collected from December 2016 to April 2017.

The data for this research were collected using the survey method and questionnaires. The samples were determined using the convenience sampling. According to Abubakar (2009), convenience sampling method is the determination of respondents conducted to customers who are chosen at random and willing to become respondents. Data collection was conducted by distributing prepared questionnaires to the respondents of importers. One method used to determine the number of samples was the Slovin formula (Sevilla et al. 1960), as follows:

$$
n=\frac{N}{1+N e^{2}}
$$

Where: $\mathrm{n}$ (number of samples); $\mathrm{N}$ (number of population); E (limit of tolerance of error (error tolerance)).

The number of KSO SCISI subscribers in 2015 was 4,540 importers so that from the above formula as many as 100 respondents were selected as the samples in this research. 
In this research, the descriptive analysis, Customer Satisfaction Index (CSI) and Costumer Loyalty Index (CLI) analysis, Importance Performance Analysis (IPA) analysis and Structural Equation Modeling (SEM) analysis were conducted.

\section{Customer Satisfaction Index}

Measurement of Customer Satisfaction Index (SCI) is required because the result of measurement is used as a reference to determine target in improving customer satisfaction in the future. The process of measuring customer satisfaction should be carried out continuously. There are four ways of calculating the customer satisfaction index according to Ikawati et al. (2011):

\section{Calculating the Weighting Factors (WF)}

This is the function of the median importance score level of each attribute in the form percentage (\%) of the total median importance score for all attributes tested.

\section{Calculating the Weighted Score (WS).}

This is the function of the median satisfaction score of the satisfaction level of each attribute multiplied by Weighting Factors (WF) of each attribute.

3. Calculating the Weighted Median Total (WMT) that is the total of the overall Weighted Scores (WS).

\section{Customer Satisfaction Index}

This is the calculation of the Weighted Median Total (WMT) divided by the maximum scale or high test scale multiplied by $100 \%$. The level of overall satisfaction of the respondents can be seen from the criteria of customers or customer satisfaction level, with the following criteria: $0.81-1.00$ (Highly satisfied); 0.660.80 (Satisfied); $0.51-0.65$ (Considerably satisfied); 0.35-0.50 (Less satisfied); 0.00-0.34 (Highly dissatisfied)

\section{Customer Loyalty Index Analysis (CLI)}

Consumer Loyalty Index (CLI) is a research method to obtain the relationship between services that have been given and the expected consumer loyalty. The measurement on customer loyalty was conducted using weighting (weight CLI) for each attribute affecting consumer loyalty. The calculation of loyalty index can be carried out as follows:

From the questionnaires given to the respondents, if they obtained that the respondents gave an answer of "willing" to the question of loyalty in each attribute, they belonged to the loyal category (Answers 4 and 5). The formula is as follows:

$$
\text { CLI }=\frac{\left.\sum_{\mathrm{i}}^{\mathrm{n}}=1 \text { (willing statement }\right) \times 100 \%}{\mathrm{~N}}
$$

According Ikawati (2011) the assessment criteria are as follows: $90.01-100.00$ (Very Loyal); 70.01-90.00 (Loyal); 50.01-70.00 (Fairly Loyal); 25.01-50.00 (Less Loyal); 00.00-25.00 (Not Loyal).

Importance Performance Analysis (IPA)

The method of Important Performance Analysis by Sugiyono (2013) and Sudikan (2010) is used to obtain information on the level of customer satisfaction to a service by measuring the level of importance and level of performance. The service quality and corporate image show how important a service attribute variable is for the customers toward the service performance. The Likert 5 scale level is used to measure the levels of importance that is very important, important, and fairly important, less important, and not important. These five levels are scored as follows: An answer of very important was given a score of 5; An answer of important was given a score of 4; An answer of fairly important was given a score of 3; An answer of less important was given a score of 2; An answer of not important was given a score of 1 .

Implementation level is the actual performance of service quality, indicating that the quality of services provided by KSO SCISI was felt by the consumers. Likert 5 scale was used to measure the levels of implementation, including very good level, good level, fairly good level, less good level, and not very good level. These five levels were scored as follows: An answer of very good was given a score of 5; An answer of good was given a score of 4; An answer of fairly good was given a score of 3; An answer of not good was given a score of 2; An answer of not very good was given a score of 1 . 
From the results of the measurement, the variables of the importance level and actual performance from the service attributes were mapped into the Cartesian diagram with four quadrants consisting of quadrant one for important and good performance, quadrant two for not important and good performance, quadrant three for not important and bad performance, and quadrant four for important and bad performance. This IPA analysis can be used to design strategies in an effort to maximize satisfaction in an efficient way that is to prioritize the attributes that are considered important first.

\section{Structural Equation Model Analysis (SEM)}

To analyze the effects of corporate image and service quality of VPTI on customer satisfaction, the effects of corporate image and service quality on customer loyalty and effects of customer satisfaction on customer loyalty and what causes the effects, the Structural Equation Model (SEM) analysis was used according to Ferdinand (2002). The service quality measured by customer perception consisted of 5 determinant dimensions, namely, tangibles, reliability, responsiveness, assurance, and empathy developed from SERVQUAL model (Parasuraman et al. 1986).

In this research, the model was built with 4 latent and indicator variables. The latent variable consisted of two independent latent variables i.e. corporate image and service quality in which a company performance variable was measured based on customer perception and 2 dependent variables, namely, customer satisfaction and customer loyalty. Each latent variable was composed by components of its forming variables called the indicator variables where each variable consisted of five indicator variables and especially for the loyalty variable, it consisted of two indicator variables.

This research measured the performance of VPTI services of KSO SCISI and the relationship between the corporate image and customer satisfaction and loyalty. Corporate image was measured based on consumer perceptions that illustrate the reputation and image of the company. Service performance was measured by SERQUAL approach (Parasuraman et al. 1986) consisting of 5 elements of Tangible, Reliability, Responsiveness, Assurance and Empathy. Satisfaction was measured based on the consumer perceptions, and it is the distance between the expectations and actual conditions received by the customers. Loyalty was measured by the consumer perceptions on their loyalty to make repeat purchases and correspond with the company. Quality of service will affect the image of the company and vice versa, and the performance of service quality and corporate image together will affect consumer satisfaction and will further affect customer loyalty as in Figure 1.

In models of SEM is hypothesized by the null hypothesis as follows: corporate image has no effect on customer satisfaction, corporate image has no effect on customer loyalty, quality of service has no effect on customer satisfaction, quality of service has no effect on customer loyalty and customer satisfaction has no effect on customer loyalty. Alternate hypothesis is that if one of the coefficients of the exogenous variables affect the endogenous variables (a variable coefficient is not equal to zero).

\section{RESULTS}

\section{Customer Satisfaction Index Analysis (CSI)}

The measurement of customer satisfaction index is required because the results are used as a reference to determine target in improving customer satisfaction in the future. The measuring process of customer satisfaction should be conducted on an ongoing basis. Table 2 shows the average scores of importance and performance of each service attribute as well as the results of the customer satisfaction index (CSI). From the analysis results, it can be seen that the index of customer satisfaction (CSI) belonged to the category of satisfaction with the score of $74.62 \%$.

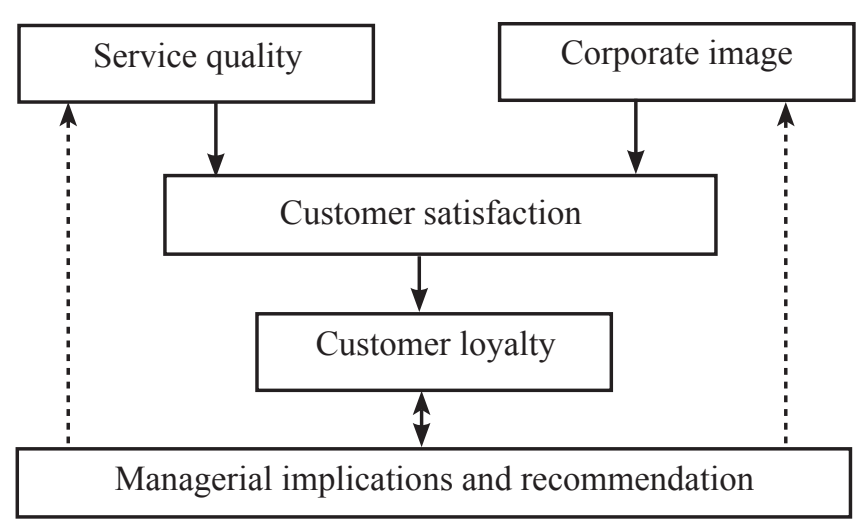

Figure 1. Research framework 
Table 2. Scores of importance, performance, CSI from the service attribute of KSO SCISI

\begin{tabular}{|c|c|c|c|c|c|}
\hline Code & Dimension & Importance & Performance & Weighting Factor (WF) & Weighting Score (WS) \\
\hline XA.1 & \multirow[t]{5}{*}{ Tangible } & 4.03 & 3.84 & 0.0403 & 0.1537 \\
\hline XA.2 & & 4.14 & 3.89 & 0.0411 & 0.1600 \\
\hline XA.3 & & 3.92 & 3.72 & 0.0389 & 0.1449 \\
\hline XA.4 & & 4.06 & 3.99 & 0.0403 & 0.1609 \\
\hline XA.5 & & 4.18 & 3.93 & 0.0415 & 0.1632 \\
\hline XB.1 & \multirow[t]{5}{*}{ Reliability } & 4.04 & 4.01 & 0.0401 & 0.1609 \\
\hline XB. 2 & & 3.65 & 3.35 & 0.0362 & 0.1215 \\
\hline XB.3 & & 4.23 & 3.28 & 0.042 & 0.1378 \\
\hline XB.4 & & 4.13 & 3.27 & 0.041 & 0.1342 \\
\hline XB. 5 & & 4.21 & 3.68 & 0.0418 & 0.1539 \\
\hline XC.1 & \multirow[t]{5}{*}{ Responsiveness } & 4.07 & 3.89 & 0.0411 & 0.1573 \\
\hline XC. 2 & & 4.23 & 4.1 & 0.3953 & 0.1723 \\
\hline XC. 3 & & 4.2 & 4.13 & 0.0417 & 0.1723 \\
\hline XC. 4 & & 4.14 & 4.04 & 0.0411 & 0.1661 \\
\hline XC. 5 & & 3.98 & 3.75 & 0.0395 & 0.1483 \\
\hline XD.1 & \multirow[t]{5}{*}{ Assurance } & 4.02 & 3.84 & 0.0399 & 0.1533 \\
\hline XD. 2 & & 3.92 & 3.4 & 0.0389 & 0.1324 \\
\hline XD. 3 & & 4.09 & 3.47 & 0.0406 & 0.1410 \\
\hline XD. 4 & & 4.08 & 3.59 & 0.0405 & 0.1455 \\
\hline XD.5 & & 3.91 & 3.64 & 0.0388 & 0.1414 \\
\hline XE.1 & \multirow[t]{7}{*}{ Empathy } & 3.83 & 3.8 & 0.0380 & 0.1446 \\
\hline XE. 2 & & 3.84 & 3.64 & 0.0381 & 0.1388 \\
\hline XE.3 & & 3.74 & 3.51 & 0.0372 & 0.1304 \\
\hline XE.4 & & 4.04 & 3.49 & 0.0401 & 0.1401 \\
\hline \multirow[t]{3}{*}{ XE.5 } & & 3.99 & 3.94 & 0.0396 & 0.1562 \\
\hline & & & & 1.000 & 3.7308 \\
\hline & & & & CSI & $74.62 \%$ \\
\hline
\end{tabular}

\section{Customer Loyalty Index Analysis (CLI)}

Consumer Loyalty Index (CLI) is an important measure to get an idea on the relationship between services given and customer loyalty expected. The measurement of the consumer loyalty index in this analysis was carried out through weighting (weight CLI). The results of the calculation of loyalty index measurement are presented in Table 3. The calculation of two indicator variables in attribute of customer loyalty obtained a CLI score of $75.70 \%$, indicating that, in general, the customers of KSO SCISI domiciled in Jakarta and its surroundings were loyal to VPTI services.

\section{Analysis on the Effects of the Corporate Image and Service Quality on the Customer Satisfaction and Customer Loyalty.}

To identify whether the corporate image and the quality of VPTI service provided by KSO SCISI had effects on customer satisfaction and loyalty, the analysis of Structural Equation Modeling Linear Structural Relationship (LISREL) was conducted. Ghozali et al. (2006) states that the SEM model is a multivariate statistical analysis technique that allows researchers to examine the direct and indirect effects of complex, recursive and non-recursive variables to obtain a comprehensive picture of a model.

Modeling through SEM makes it possible to answer both regressive and dimensional research questions, which measure the dimensions of a concept in research (Ferdinand, 2002). The attribute of service quality is explained by five indicators (Parasuraman et al. 1986), namely, tangible, reliability, responsiveness, assurance, and emphasis. Also, in the attribute of corporate image, the customer satisfaction is explained by the five indicator variables, while the loyalty is explained by two indicator variables. 
To get a good model in SEM analysis, it is necessary to carry out the testing on a number of criteria as presented in Table 4. Based on the measurement in Table 4, all indicators indicated that the SEM model was Good Fit, indicating that the data from the questionnaire results had been able to answer the theory built in this model. Testing on the outer loading aimed to see the correlation among the score items or indicators with their variable scores. An indicator is considered to be reliable if it has a correlation score above 0.7 , but in the development phase, the value of 0.50 is still acceptable (Ghozali, 2006). The results of the standardized loading factors in Figure 3 show that all attributes of corporate image, service quality, customer satisfaction consisting of five indicator attributes and of customer loyalty consisting of two indicator attributes in the model were considered to be reliable so that they could continue to be analyzed.

The feasibility of a model can also be seen from its $\mathrm{t}$-statistic value, provided that the $\mathrm{t}$-statistic value must be greater than $\mathrm{t}$ - table of 1.960 at the 0.05 significance level. The result of T-count scores on the model are presented in Figure 4.

From the results of the calculation of Standardized Loading Factor value of Figure 3 and the T-count scores in Figure 4 presented in Table 5, it can be concluded that the model in this research was feasible and reliable. Almost all attribute indicators had a Standardized Loading Factor score above 0.70, and only a few had less than 0.70 i.e. the tangible attribute with the score of 0.67 , the corporate image dimension 3 with the score of 0.65 , and the satisfaction dimension 4 with score of 0.68 . As mentioned by Ghozali (2006), an indicator is considered to be reliable if it has a correlation score above 0.7 , but in the development phase, the score of 0.50 is still acceptable. The result of the calculation of the scores of T-count shows that all of the indicator attributes had T-count scores above 1.96 that is they were significant at $\alpha$ level of $5 \%$. Thus, all attributes in the model are declared to be feasible and reliable.

\section{Hypothesis Testing}

Hypothesis testing was based on the scores from the structural model analysis, significance level of the path coefficient obtained from the t-score and the standardized path coefficient score. The threshold score or threshold hypothesis testing is that the t-score of its loading factor is greater than the critical value $(\geq 1.96)$ and the standardized path coefficient (p) score was $\geq 0.05$. Summary of the hypothesis testing results can be seen in Table 6 .

Table 3. Results of customer loyalty index calculation (CLI)

\begin{tabular}{ccc}
\hline Loyalty Attribute & Performance & Score of CLI (\%) \\
\hline LOY 1 & 3.70 & 74.00 \\
LOY 2 & 3.87 & 77.40 \\
Average & & 75.70 \\
\hline
\end{tabular}

Table 4. The result of the conformity criteria of the SEM research model

\begin{tabular}{lccc}
\hline \multicolumn{1}{c}{ Goodness-of-Fit } & Cutt-off-Value & Result & Description \\
\hline RMR (Root Mean Square Residual) & $\leq 0.05$ atau $\leq 0.1$ & 0.066 & Good fit \\
RMSEA (Root Mean square Error of Approximation) & $\leq 0.08$ & 0.000 & Good fit \\
GFI (Goodness of Fit) & $\geq 0.90$ & 0.99 & Good fit \\
AGFI (Adjusted Goodness of Fit Index) & $\geq 0.90$ & 0.98 & Good fit \\
CFI (Comparative Fit Index) & $\geq 0.90$ & 1.00 & Good fit \\
Normed Fit Index (NFI) & $\geq 0.90$ & 0.98 & Good fit \\
Non-Normed Fit Index (NNFI) & $\geq 0.90$ & 1.00 & Good fit \\
Incremental Fit Index (IFI) & $\geq 0.90$ & 1.00 & Good fit \\
Relative Fit Index (RFI) & $\geq 0.90$ & 0.98 & Good fit \\
\hline
\end{tabular}




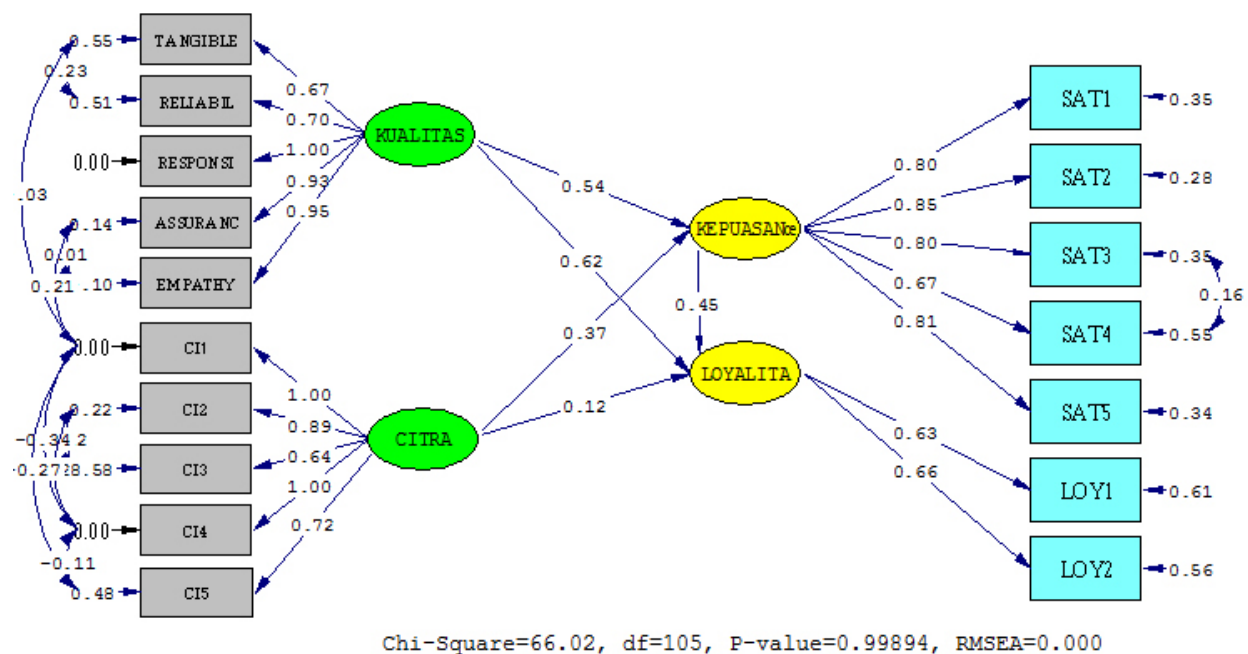

Figure 3. Standardized loading factor of the research SEM Model

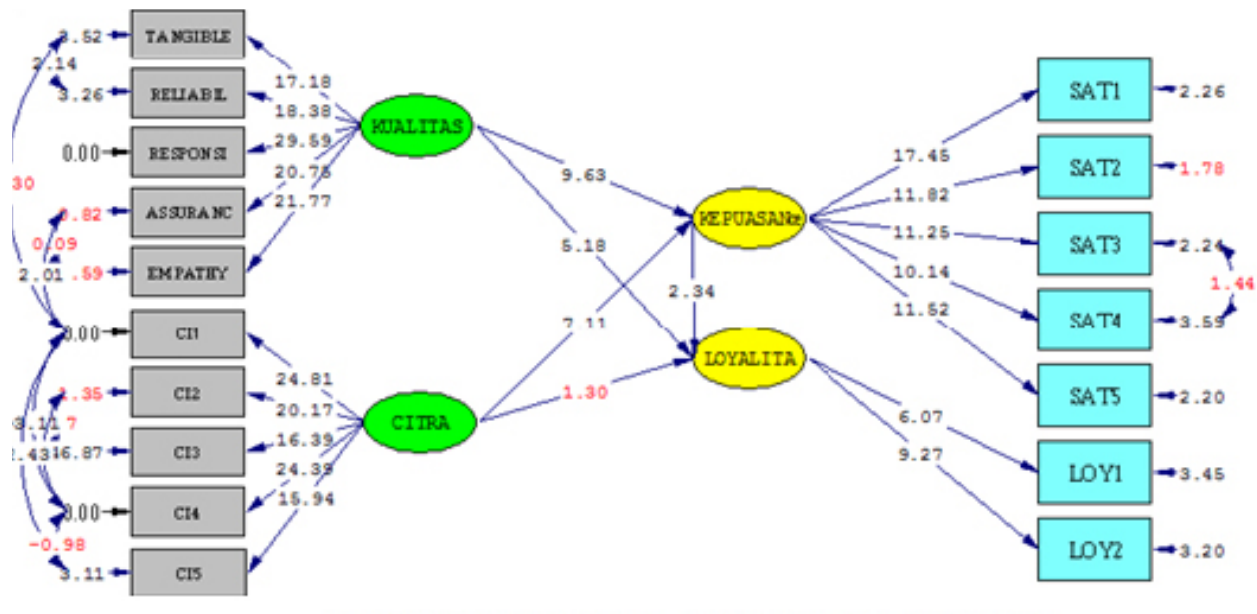

Chi-Square $=66.02$, df $=105, \mathrm{p}-$ value $=0.99894, \mathrm{RMSEA}=0.000$

Figure 4. The calculation of the scores of T-count of the research SEM model

Table 5. The measurement model of the variables of service quality, corporate image, satisfaction and loyalty of the customers of KSO SCISI

\begin{tabular}{lcc}
\hline \multicolumn{1}{c}{ Indicator name } & Standardized loading factor & T-count \\
\hline Tangible & 0.67 & 10.47 \\
Reliability & 0.70 & 20.01 \\
Responsiveness & 1.00 & 31.95 \\
Assurance & 0.93 & 22.77 \\
Empathy & 0.94 & 23.69 \\
Corporate image1 (CI1) & 1.00 & 27.56 \\
Corporate image2 (CI2) & 0.89 & 21.48 \\
Corporate image3 (CI3) & 0.65 & 17.93 \\
Corporate image4 (CI4) & 1.00 & 25.88 \\
Corporate image5 (CI5) & 0.70 & 17.47 \\
Satisfaction 1 (SAT1) & 0.82 & 16.82 \\
Satisfaction 2 (SAT2) & 0.84 & 13.25 \\
Satisfaction 3 (SAT3) & 0.78 & 12.55 \\
Satisfaction 4 (SAT4) & 0.68 & 11.46 \\
Satisfaction 5 (SAT5) & 0.81 & 12.95 \\
Loyalty 1 (LOY1) & 0.77 & 10.14 \\
Loyalty 2 (LOY2) & 0.84 & 10.56 \\
\hline \hline
\end{tabular}


Table 6. Hypothesis testing based on the research with the SEM Model

\begin{tabular}{lccc}
\hline \multicolumn{1}{c}{ Hypothesis } & Standardized loading factor & $\mid$ T-count $\mid$ & Description \\
\hline Service quality $\rightarrow$ Satisfaction & 0.54 & 9.91 & Significant \\
Corporate image $\rightarrow$ Satisfaction & 0.37 & 7.26 & Significant \\
Service quality $\rightarrow$ Loyalty & 0.64 & 8.50 & Significant \\
Corporate image $\rightarrow$ Loyalty & 0.23 & 4.22 & Significant \\
Satisfaction $\rightarrow$ Loyalty & 0.20 & 0.03 & Insignificant \\
\hline
\end{tabular}

The first hypothesis was the effects of service quality on customer satisfaction. The SEM results show the loading factor score of 0.54 with the absolute T-count score of 9.91. The T-count score was greater than $t$ table alpha $5 \%$ i.e. 1.96 , indicating that the effects of service quality on customer satisfaction was significantly positive. This means that if the service quality service increases, it will directly increase customer satisfaction. This result is consistent with the research results of Subagio and Saputra (2010), indicating that service quality has a significantly positive effect on customer satisfaction. This is reinforced by the previous research by Wendha et al. (2013), Annisa (2014), Seravine (2016), and Manu (2016) who stated that the service quality has a significantly positive impact on customer satisfaction.

The second hypothesis was the effects of corporate image on satisfaction. The SEM results show the loading factor score of 0.37 with the absolute T-count score of 7.26. This T-count score was greater than $\mathrm{t}$ table alpha $5 \%$ of 1.96 , indicating that the effects of the corporate image on satisfaction were positively significant which means that if the corporate image increases, it will directly increase customer satisfaction. These results are consistent with the research result of Kotler (2001) who explained that building an important image for the continuity of the organization in the future is important, and this was reinforced by the previous research of Rahyuda (2011) who stated that corporate image is positively significant to customer satisfaction. This is also supported by Safitri (2016) stating that corporate image has a significant effect on customer satisfaction. The third hypothesis was the effects of the service quality on the customer loyalty. The SEM results show the loading factor score of 0.64 with the absolute T-count score of 8.50. This score was greater than $t$ table alpha $5 \%$ of 1.96 which means the effects of the service quality on customer loyalty are significant and positive, indicating that if the service quality increases, it will directly increase the customer loyalty. These results are consistent with the results of the research of Subagio and Saputra (2010) who found a positive relationship between service quality and customer loyalty, and this was further supported by the research conducted by Wahyudi (2016) who state that service quality has a significantly positive effect on customer loyalty.

The fourth hypothesis was the effects of corporate image on customer loyalty. The SEM results show the loading factor score of 0.23 with the absolute T-count score of 4.22 which was greater than t table alpha $5 \%$ of 1.96 , thus indicating that means the effects of corporate image on loyalty were significant and positive. Therefore, if the corporate image increases, it will directly affect the increase of customer loyalty. Parasuraman et al (1996) state that when there is satisfaction in the consumer, the company products can obtain a good image from the consumers, and in turn, the company will gain its consumer loyalty. The research conducted by Safitri (2016) supported this hypothesis that the corporate image have significant effects on customer loyalty.

The fifth hypothesis was the effects of customer satisfaction on customer loyalty. The SEM results show the loading factor score of 0.01 with the absolute $\mathrm{T}$-count of 0.03 , and this score was smaller than $\mathrm{t}$ table alpha $5 \%$ of 1.96 , indicating that the effects of customer satisfaction on customer loyalty are not significant. Therefore, if satisfaction increases or decreases, it will not affect loyalty. These results are consistent with Gultom et al. 2016 stating that customer satisfaction has no effects on customer loyalty. As it is known that the market faced by the service company of KSO SCISI on VPTI services is a monopoly market; as a result, customers are always loyal even though they are not satisfied. This is the same market as faced by the Perhutani Company (Gultom et al. 2016)

Importance Performance Analysis (IPA)

The IPA method was used to obtain information on the level of customer satisfaction toward a service by measuring the levels of importance and performance. From the result of the measurement, the variables of the importance level and actual performance from the 
service attribute and corporate image were mapped into the Cartesian diagram with four quadrants. Figure 5 shows the results of IPA analysis showing the position of the attributes in each quadrant.

The IPA method was used to obtain information on the level of customer satisfaction toward a service by measuring the levels of importance and performances. From the result of the measurement, the variables of the importance level and actual performances from the service quality attribute were mapped into the Cartesian diagram of four quadrants. Figure 4 shows the results of IPA analysis showing the position of attributes in each quadrant.

Quadrant one of the main priority position that is the performances were below average and importances were above average, indicating that all attributes of the service quality that existed in this position were perceived by the customers as important attributes but their performances were perceived to be low so that this position is called the main priority position. Therefore, the performances of these attributes in this position should be prioritized to be improved. The attributes included B3 (alertness in recording and saving documents without errors), B4 (easy access to check the progress of the processing flow of the document submitted and to monitor the VO status via VPTI
Online), D3 (knowledge and accuracy of the officers of KSO SCISI in performing the document inspection until the publication of LS), E4 (convenient operating time at KSO SCISI).

The second quadrant is to keep up with the achievements in which the performances and importances were above average. This means that all attributes of service quality that exist in this quadrant were assessed by the customers as attributes with important positions, and the scores of the performances of the attributes were considered to be good. Therefore, the positions of those attributes are necessary to be maintained for the achievement of a higher satisfaction index. The attributes included A2 (availability of clean and comfortable offices and waiting rooms), A5 (availability of a KSO SCISI website for VPTI services that is easy to access), B1 (the officers are available at service time), B5 (the officers of KSO SCISI can solve problems well), C2 (speed of the Call Centers in serving customer complaints), $\mathrm{C} 3$ (speed of the Call Centers in answering questions related to the current verification progress), C4 (the officers' awareness in providing solutions to customers), D1 (Understanding of the Call Centers on KSO SCISI services as a whole), E5 (existence of a good communication pattern between customers and the officers of KSO SCISI).

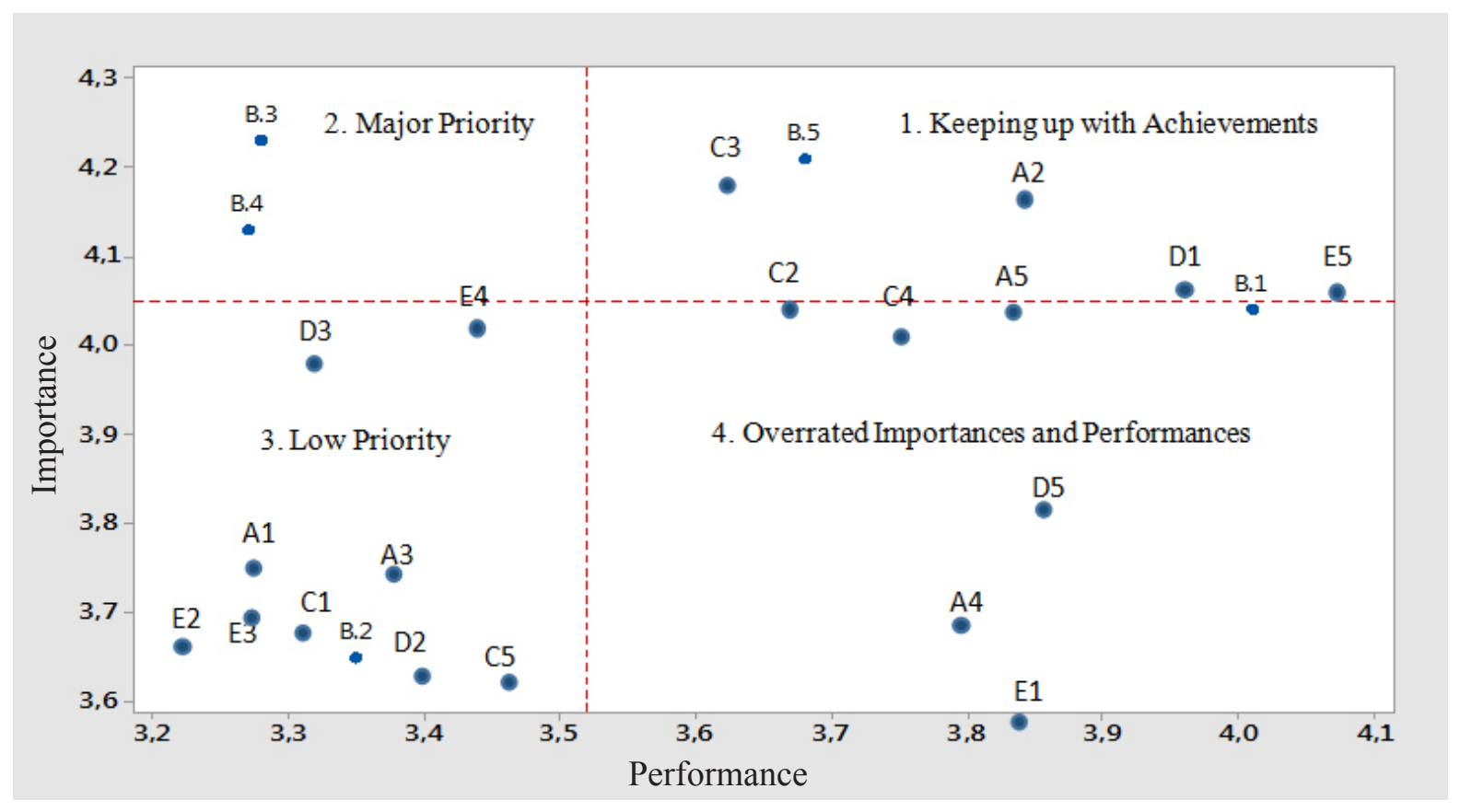

Figure 5. The results of the Importance Performance Analysis (IPA) 
Quadrant three is the low priority position that is the importance and performance have below average scores, indicating that the customers considered all of the attributes of service quality to be less important and their performances are also reasonably poor. These attributes included A1 (a strategic location makes it easy for customers to reach KSO SCISI service offices), A3 (availability of adequate office facilities and infrastructure), B2 (completion of the VPTI services offered in accordance with the set up time/SOP), C1 (speed of the Call Centers in providing answers to the questions from the customers), C5 (eagerness of the officers in responding the customer demands), E2 (seriousness in prioritizing the customer importances), E3 (understanding of the officers of KSO SCISI on the customer needs).

The fourth quadrant is the overrated position (Posisi Berlebihan) that is the performances were above average and importances were below average, indicating that all attributes of service quality assessed by the customers had less important positions; however, they believed that the company had implemented its good performances. Therefore, these attributes were overrated because the performances should be focused on improving the important attributes first. These attributes included A4 (the officers of the customer service are attractive and serve customers well), D5 (punctuality in accordance with the established standards), E1 (the officers give individual attention to the customers).

\section{Managerial Implication}

The results of this research prove that the improvement of service quality and corporate image has significantly positive effects on satisfaction and loyalty; therefore, the service quality and corporate image need to be improved in a sustainable manner. Based on the IPA analysis, the service qualities prioritized by the company using the marketing mix strategy (4P) of Kotler (2001) are as follows:

1. Improvement on the quality of human resources by the company by providing understanding, training, socialization and workshop activities to employees on an ongoing basis so that verification officers can perform their duties properly, competently and slightly make mistakes.

2. Continuous improvement by the company so that the business process can run better, faster, safer and more accurately by developing a system of mutual control on the officers supported by the development of information technology.

3. Improvement on infrastructures both in the form of hard and soft infrastructures to develop better on line services which are easily accessed by customers and availability of an updated and informative website by the company.

4. longer service hours by opening services outside working hours and in working days by enabling shift hours and picketing off hours and in working days so that customers can obtain convenient operator hours suitable with their importance

5. Implementation of a service diversification that is providing a fast, medium or slow lane service with prices based on the speed level so that customer can adjust with their requirement, and the prices they pay will comply with what they expect.

\section{CONCLUSIONS AND RECOMMENDATIONS}

\section{Conclusions}

Based on the calculations of CSI and CLI, the levels of satisfaction and loyalty were $75.21 \%$ and $74.20 \%$ respectively. This shows that the levels of the customer satisfaction and loyalty on the corporate image and service quality belong to the satisfied and loyal categories.

The results of the SEM LISREL test show that corporate image significantly has positive effects on customer satisfaction with $\alpha$ level of $5 \%$, and service quality significantly has positive effects on customer satisfaction with $\alpha$ level of $5 \%$. Corporate image significantly has positive effects on customer loyalty with $\alpha$ level of $5 \%$, and service quality significantly has positive effects on customer loyalty with $\alpha$ level of $5 \%$, and customer satisfaction significantly has significant positive effects on customer loyalty with $\alpha$ level of $10 \%$.

Based on the results of IPA analysis on the managerial implications, satisfaction and loyalty of the customers of KSO SCISI on the VPTI services can be improved by: (1) increasing the quality of human resources by providing understanding, training, socialization, workshop activities so that the verification officers can perform their duties properly and competently and slightly make mistakes; (2) improving the business 
process so that it runs better, faster, safer and more accurately by developing a system of mutual control on the officers supported by the development of information technology; (3) improving infrastructure in the form of hard and soft infrastructure to develop better and accessible online services by customers and having a website that is always updated and informative; (4) offering longer service hours by opening services outside working hours and in working days by enabling shift hours and picketing off hours and in working days so that customers can obtain convenient operator hours suitable with their importance; and (5) conducting a service diversification that is providing a fast, medium or slow lane service with prices based on the speed level so that customer can adjust with their requirement, and the prices they pay will comply with what they expect.

\section{Recommendations}

Based on the conclusions obtained in this research, the recommendations for further research are as follows: KSO SCISI should maintain the performances of the corporate image and service quality that are considered as good by the customers. The company should also continue to make innovations to improve the service quality because customer demands continue to grow in line with the developments of technology and information and customer experience. Future research is expected to add more regional domicile customers coming from all over Indonesia. This research only included the customers domiciled in Jakarta and its surrounding areas. Further research is expected to be able to distinguish verified commodities, because each commodity has a different behavior, and it implies the verification process.

\section{REFERENCES}

Afsar A, Nasiri ZMO. 2013. E-Loyalty Model in E-Commerce . Mediterranean Journal of Social Science. MCSER Publishing Rome-Italy 4(9): 547-553.

Anzie LP, Arifin Z. 2015. Pengaruh kualitas layanan terhadap citra perusahaan, kepuasan dan loyalitas pelanggan( Studi pada Nasabah Pengguna Produk Tabungan BCA di Wilayah Rungkut Mapan, Surabaya. E-Journal Fakultas Ilmu Administrasi Universitas Brawijaya 9(2): 9-22.

Annisa AR 2014. Pengaruh kualitas pelayanan jasa verifikasi impor terhadap kepuasan dan loyalitas pelanggan di PT. Surveyor Indonesia (Persero). [tesis]. Bogor: Institut Pertanian Bogor

Dhiranty A, Saharjo B, Supriyatno G. 2017. An analysis on customer satisfaction, trust and loyalty toward online shop (a case study of tokopedia.com). Indonesian Journal Of Business And Entrepreneurship (IJBE) 3(2):102-110. doi:http://dx.doi.org/10.17358/ijbe.3.2.102

Ferdinand A. 2006. Metode Penelitian Manajemen. Ed ke- 2. Semarang: Universitas Diponegoro.

Ghozali I. 2006. Aplikasi Aplikasi Analisis Multivariate dengan program SPSS. Semarang:Penerbit Universitas Diponegoro.

Gultom WST, Yuliati LN, Djohar S. 2016. Pengaruh service quality, product quality and perceived value terhadap kepuasan dan loyalitas pelanggan industri kayu Perhutani. Jurnal Manajemen \& Agribisnis 13(2):109-121.

Hami MLS, Suharyono, Hidayat K. 2016. Analisis pengaruh nilai pelanggan terhadap kepuasan pelanggan dan dampaknya pada loyalitas pelanggan (survei pada pengguna sepeda motor honda Vario All Variant di Service Center Honda AHASS Sukma Motor Jalan Sigura-gura Barat Kota Malang). Jurnal Administrasi Bisnis (JAB) 39(1).

Hidayat DR, Firdaus MR. 2014. Analisis pengaruh kualitas layanan, harga, kepercayaan, citra perusahaan dan kepuasan pelanggan terhadap loyalitas pelanggan (Studi pada pelanggan Telkom Speedy di Palangkaraya. Jurnal Wawasan Manajemen 2(3): 237-249.

Ikawati NL.Sumarwan U. Yuliati LN 2011. Analisis kepuasan dan loyalitas pengunjung departement store pasaraya Blok M [tesis]. Bogor: Institut Pertanian Bogor.

[KEMENDAG] Kementerian Perdagangan Republik Indonesia. 2014. Permendag 48/M-DAG/ PER/7/2015 tentang Ketentuan Umum di bidang impor. Jakarta: KEMENDAG.

Kotler P, Garry A. 2001. Prinsip-prinsip Pemasaran. Edisi 8. Jakarta : Erlangga.

KSO SCISI [Kerjasama Operasi Sucofindo - Surveyor Indonesia]. Profil. http://scisi.co.id/scisi/id/ [10 Oktober 2017].

Manu VM. 2016. Analisis persepsi nilai pelanggan dan persepsi nilai program terhadap kepuasan pelanggan dan pengaruhnya pada loyalitas pelanggan dan niat pembelian kembali: studi frequent flyer program Garuda Miles [thesis]. Yogyakarta: Universitas Gadjah Mada. 
Nugroho NT. 2015. Pengaruh Kualitas Pelayanan terhadap Kepuasan dan Loyalitas Pelanggan (Survey pada Pelanggan Speedy Telkom di Kota Surakarta. Jurnal Paradigma 12(2): 114-122.

Nurfina O. Haryono AT. Minarsih MM. 2016 Analisis pengaruh e-commerce strategy, service performance terhadap loyalitas pelanggan dan kepuasan pelanggan sebagai variable intervening (studi empiris Garuda Online Shop. Journal of Management V1 2(2).

Ong JO, Pambudi J. 2014. Analisis kepuasan pelanggan dengan Importance Performance Analysis di SBU Laboratory Cibitung PT. Sucofindo (Persero). Jurnal J@TI Undip IX(1): 1-10.

Panjaitan FAB. 2014. Analisis kepuasan pelanggan PT. Sucofindo (Persero) melalui kualitas layanan dan citra perusahaan. Jurnal Ilmu Ekonomi \& Manajemen 1(2): 140-150.

Parasuraman, A. Zeitthaml VA. Berry LL.1985. A Conceptual Model of Service quality and it's implacation for future research. Journal of Marketing 49: 41-50. https://doi. org/10.2307/1251430.

Prihanto A. 2013. Kepuasan dan loyalitas konsumen korporat untuk acara mice terhadap kualitas pelayanan Hotel HSTH. Journal Manajemen dan Kewirausahaan 15(2): 165-178. https://doi. org/10.9744/jmk.15.2.165-178.

Rifai A, Suryani A. 2016. Peran customer perceived value pada kepuasan pelanggan tiket online. E-Journal Manajemen UNUD 5(6): 3305-3304.

Safitri E. 2016. Pengaruh kualitas pelayanan dan citra perusahaan terhadap kepuasan pelanggan dan loyalitas pelanggan service center (studi pada pelanggan samsung service center di Kota Malang). Jurnal Ekonomi Bisnis 21(1): 91-104.
Seffy VT, Suwignjo P, Santosa B. 2014. Analisa pengaruh kualitas pelayanan, kepercayaan, komplain dan kepuasan pelanggan terhadap loyalitas pelanggan (studi kasus: PT. Garuda Indonesia Palembang). ITS Journal 2014: 1-16.

Seravine IA. 2016. Pengaruh kualitas pelayanan, kepercayaan, komplain dan kepuasan pelanggan terhadap loyalitas pelanggan bengkel Toyota Nasmoco Solo Baru [tesis]. Yogyakarta: Universitas Atmajaya Yogyakarta.

Sevilla CG, Ochave JA, Punsalan TG, Regala BP, Uriarte GG. 1960. Research Methods. Quezon city: Rex printing Company.

Subagio H, Saputra R. 2012. Pengaruh perceived service quality, perceived value, satisfaction dan image terhadap customer loyalty (studi kasus Garuda Indonesia). Jurnal Manajemen Pemasaran 7(1): 42-52. doi: 10.9744/pemasaran.7.5.42-52.

Sudikan. 2010. Studi tentang Kualitas Pelayanan PT. PLN (Persero) unit Pelayanan dan Jaringan Semarang Barat [tesis]. Semarang: Undip.

Sugiyono. 2013. Metode Penelitian Pendidikan Pendekatan Kuantitatif, Kualitatif, dan $R \& D$. Bandung: Alfabeta.

Wahyudi D. Hartoyo. Yuliati LN. 2015. Analisis Kepuasan dan Loyalitas Pelaku usaha terhadap Mutu Pelayanan Pengujian Alat dan Mesin Pertanian. Jurnal Widyariset 18(2): 207-214.

Wendha AP, Rahyuda IK, Suasana IGAK. 2013. Pengaruh citra perusahaan dan kualitas pelayanan terhadap kepuasan dan loyalitas pelanggan Garuda Indonesia di Denpasar. Journal Manajemen Kewirausahan 7(1):31-46.

Yesenia, Siregar EH. 2014. Pengaruh kualitas layanan dan produk terhadap kepuasan serta loyalitas pelanggan KFC di Tangerang Selatan. Jurnal Manajemen dan Organisasi 5( 3): 184-199. 